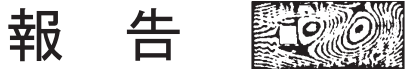

\section{9 年度日本風工学会優秀修士論文賞 選考経過 \\ Progress Report of Selection of the Winners for the Master Thesis Awards of JAWE}

第 22 期運営 - 学術委員会 委員長 奥田 泰雄*

Yasuo OKUDA

2019 年度日本風工学会優秀修士論文賞の候補者募集の 案内を, 日本風工学会誌第 44 巻第 4 号 (通巻 161 号), 第 45 巻第 1 号 (通巻 162 号) の会告・案内および本会木 ームページへ掲載するとともに，全会員へ案内をメール 送信して周知を図った。その結果，本年度は 4 件の応募 があった。これらの応募に関して, 2020 年 2 月 20 日開催 の運営・学術委員会にて，応募書類および論文概要の内 容確認を行ったのち, 授賞候補者を審議した。その結果, 4 名を候補として理事会に推薦した。推薦結果は, 理事会 の審議を経て, 2020 年 2 月 25 日に下記の通り授賞者が決 定した。

1. 林 超（東京大学大学院 工学系研究科建築学専攻） 論 文名: 単体建物周辺における高温排気ガスの拡散予 測に関する研究

授賞理由 :

本論文は，建築物周辺に設置された非常用発電機から 極めて温度の高い排気ガスが排出される想定の下，風洞 実験およびCFD 解析を通し，その大気拡散に関する知見 を蓄積寸るものとなる。本研究は, 数值解析や風洞実験 といった多彩なアプローチを用いた分析により展開され ることで，その研究成果の信頼性を担保している。加え て本研究の遂行は, 候補者が専門分野とする建築・都市 環境工学のみならず流体力学や気象学等, 幅広い分野の 基礎知識を必要とするものであり，候補者の研究姿勢は 高い評価に值する。以上の理由により，林 超氏に優秀修 士論文賞を授与する。
2. 小林 俊之（横浜国立大学大学院 都市イノベーショ 之学府 都市地域社会専攻)

論 文名: 海面水温特性に着目した台風シミュレーショ ンの再構築

授賞理由：

構造物の設計風速や海洋での台風の影響を統計的に評 価するために用いられる台風モンテカルロシミュレーシ ヨンにおいて, 海面水温を考慮する方法に関する研究で ある。本論文の特徵は, シミュレーション全体にわたっ て様々な工夫や改良が加えられていることであり，その 有効性も検証されている。研究のレベルから見ると一つ 一つの改良や工夫には議論の余地が残されているが，丁 寧にかつ研究目的に応じたバランスを以て問題に取り組 んでいる。その結果，海面水温の評価方法，移動に伴う 台風パラメータの更新, 発生と消滅等の取り扱い方法, 上空風と地上風の関係などに学術的に成果をもたらして いる。以上の理由により，小林俊之氏に優秀修士論文賞 を授与する。

3. 水越 裕紀 (新潟大学大学院 自然科学研究科環境科 学専攻)

論 文名：自然換気の非定常性に関する研究 単独及び 複数建物モデルを対象とした風圧変動による 自然換気

授賞理由：

本論文は, 建物周辺気流の非定常変動が建物内の自然 換気に与える影響に注目し，乱流解析モデルを用いた数 值実験によってその定量的評価を試みた研究である。単

国立研究開発法人建築研究所 構造研究グループシニアフェロー 
体建物および複数建物モデルの周辺気流を対象とした Large-eddy simulation を実施し, 開口部位置における風圧 変動の時系列データを取得するとともに，その風圧デー 夕を入力値とした換気回路網計算によって, 建物内の自 然換気量を予測している。その結果, 建物周辺気流の変 動による自然換気量が, 特に風向に直交する向きの 2 開口 の組み合わせにおいて無視しえない大きさとなることを 明らかにした。本研究は, 建物周辺気流の変動特性が, 建物内の換気にも大きな影響を与えうることを定量的に 実証した点において，換気現象の理解および予測手法の 発展に寄与するものであり, その学術的な価值も認めら れる。以上の理由により, 水越裕紀氏に優秀修士論文賞 を授与する。

4. 浜田 翼 (東京工業大学 環境 - 社会理工学院 建築 学系都市・環境学コース)
論文名：LES で推定された建築物の空力特性の不確定 性定量化

授賞理由 :

本論文は, LES による建築物の風圧力・風力推定にお ける流入条件の不確定性の影響を定量的に評価したもの である。これまで計測に対して行われることがほとんど であった不確定性評価を数值シミュレーションに適用し てLES の予測結果の信頼性を定量評価した点において 本論文は評価できる。不確定性評価では, 多項式カオス を用い, 少ないサンプル数からでも風向角やレイノルズ 数といった流入条件が空力特性のばらつきに与える影響 を評価するなど創意工夫が伺える。本論文は，これまで 定量的に示されてこなかったLES の予測結果に対する 不確定性について論じられた新規性のある内容であると 判断される。以上の理由により, 浜田翼氏に優秀修士論 文賞を授与する。 